\title{
Friday charity Program to Meet the SDGs No. 2
}

\author{
$1^{\text {st }}$ Ahmad Syukron Prasaja ${ }^{1}, 2^{\text {nd }}$ Hesti Riany $^{2}, 3^{\text {rd }}$ Siti Raudhatul Jannah ${ }^{3}, 4^{\text {th }}$ Mardalina $^{4}, 5^{\text {th }}$ \\ Rita Syafitri ${ }^{5}$ \\ \{ syukronprasaja@uinjambi.ac.id ${ }^{1}$, hestiriany@uinjambi.ac.id ${ }^{2}$, sitiraudhatuljannah@uinjambi.ac.id ${ }^{3}$, \\ lena74marlina@gmail.com ${ }^{4}$, syafitririta@uinjambi.ac.id ${ }^{5}$ \} \\ UIN Sulthan Thaha Saifuddin Jambi ${ }^{1,2,3,4}$
}

\begin{abstract}
Covid-19 has a massive impact on all aspects. The most widely felt impact is a decrease in economic activity that impacts declining incomes. One of the contributing impacts is the reduced access to food (food insecurity) of some students and staff of UIN Sulthan Thaha Saifuddin Jambi to good food due to low income. UIN Sulthan Thaha Saifuddin Jambi tried to overcome this problem by registering students and staff who experienced food insecurity using survey123. Then conducting a Charity Program by providing free food every Friday by Dharma Wanita Persatuan (DWP) and Center for Demographic, Ethnography, and Social Transformation Studies named Friday Charity Program. This study aims to understand how Friday Charity Program can overcome food insecurity for students and staff at university. The result was that Friday Charity Program could help the people that need food. This activity is also one of the university's concerns in achieving the 2nd Sustainable Development Goals (SDGs), namely No Hungry.
\end{abstract}

Keywords: Charity, Friday Charity, Food Insecurity, No Hungry, SDGs

\section{Introduction}

The covid-19 pandemic was announced on March 3, 2020, by the Indonesian government [1] and started entering Jambi at the end of March 2021, precisely on March 23 [2]. It is still ongoing to date to have an economic impact, even reducing Indonesia's economic growth by $2.07 \%$ from 2020 [3]. This condition causes some financial problems such as job loss, both primary and side for some people [4]. Bahkan di Inggris, dampak tidak langsung dari pandemic covid-19 ternyata mengekspos inequality food system yang meningkatkan kemiskinan [5]. Many unemployed people impact declining income, raising new food insecurity issues discovered in students and university staff. Even until this writing was done, Jambi has begun to impose Restrictions on Community Activities (PPKM) level 4 from 23 to August 29, 2021 [5]. With PPKM level 4, the community should not do any activities outside the home except crucial sectors. Of course, the establishment of PPKM level 4 can aggravate the condition of the community that depends on the private sector. Although with the implementation of PPKM level 4 already has a success story like in Jakarta that has entered the green zone and meets Herd Immunity [7]

As social creatures, humans coexist with other humans. In society, all human beings must have a concern for others. Social assistance is a form of attitude and behavior that expresses respect for others and communities in need of values such as honesty, kindness, humility, friendliness, and kindness [8]. The importance of cultivating compassionate attitudes must be realized as early as possible so that values permeate society. Social work plays an essential role 
in shaping socially sensitive individuals. His attitude and behavior are always willing to help those in need.

Indonesian universities should organize education, research, and community service, commonly known as Tridharma Higher Education [9]. Based on the obligations of tri dharma, the university as higher education has a responsibility to address the social problems of its campus community [10]. The same obligation is also attached to UIN Sulthan Thaha Saifuddin (STS) Jambi. The emergence of declining income problems impacts some contract staff, honorees, and parents of students. The impact of decreased income for parents of students directly affects student finances. If this continues, then food insecurity may appear.

In France, the federal government implemented financial assistance program for food charities to mitigate the covid-19 effect [11]. Even in Italy, blockchain has been used as one form of charity 4.0 during the covid-19 pandemic. [12]. In Indonesia, many social services Implemented, such as sharing Covid-19 Care sembako (nine basic food needs) packages at Boarding School Bukit Tengkorak Ndao Kabupaten Ende Flores [13], Regular sharing activities to pilgrims every Friday and the residents of Jalan Batu Besaung during Ramadan 2020 [14], sharing sembako (nine basic food needs) for informal worker that effected Covid-19 [15], Sharing masks to one group of community who are very vulnerable is traditional market traders in the Medan Province by the academic community of Sari Mutiara University of Indonesia [16]. Besides the government and universities, CSR is also involved in helping the community, such as cooperation between BSM and the National Amil Zakat Institution Bangun Sejahtera Mitra Umat (LAZNAS BSM) was built by Yayasan Bangun Sejahtera Mitra Umat (BSM Umat) in helping people affected by covid-19. [17]. Another form of CSR assistance is provided to MSMe (UMKM) in capital fulfillment after capital outflow due to the covid-19 pandemic [18]. There is also economic empowerment of the community after the covid-19 pandemic by PT. Pertamina [19].

Zero Hunger is one of the sustainable development goals (SDGs) number 2 [8]. Staff and students affected by Food insecurity need to find solutions by the university. According to previous research, sharing activities held by some institutes are not carried sustainable events. Therefore, the Center for Demographic, Ethnography, and Social Transformation Studies, in collaboration with Dharma Wanita Persatuan UIN STS Jambi to provide solutions by conducting Friday Charity Program as a form of university service to the community to ease the burden of staff and students, especially those affected by food insecurity sustainably, so that they can easily access food

\section{Methodology}

\subsection{Planning Stage}

The Center for Demographic Studies, Ethnography, and Social Transformation coordinates with Woman Associaton named Dharma Wanita Persatuan (DWP) UIN STS Jambi planning and coordinating to conduct Friday Charity Program (Figure 1). This coordination resulted in a division of tasks. DWP UIN STS Jambi was tasked with providing food for Friday Charity Program, and The Volunteer Korsp (KSR) of UIN STS Jambi distributed free food. In addition to charity on Fridays in this stage, it also carried out free food sharing activities during Ramadan $1442 \mathrm{H} / 2021 \mathrm{M}$. It continues to do so twice per month to be carried out sustainably. 


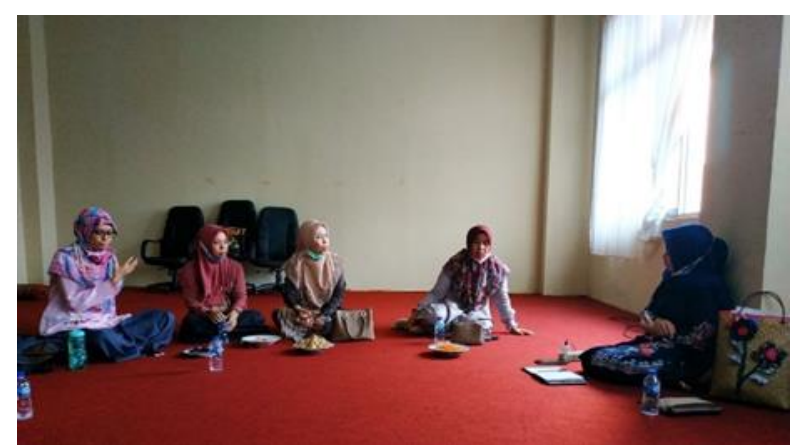

Fig. 1. Coordination Meeting between Center for Demographic Studies, Ethnography, and Social Transformation with DWP UIN STS Jambi to conduct Friday Charity Program

Identify UIN STS Jambi students who need to use the Survey123 application at the following link https://arcg.is/0ybLr1. Survey 123 It is one of the web-based applications developed by ESRI. This application can be used as an online questionnaire with the added value of location information of each respondent who fills out the questionnaire [21]. The population of this research is all students and low-income staff such as cleaning service, contract staff, and honorees. The food insecurity condition of students and staff is identified through the current cost of living, how many meals in a day, how much is used for one meal, parental work, and parental income. All of these variables are clarified with questions of nutritional status information, especially for our staff, select cleaning service workers, and security guards.

\subsection{Implementation Stage}

Friday Charity activities are carried out in the form of sharing food with students and staff. This activity is held once every two months. The free food provided by DWP UIN STS Jambi results from fundraising from the academic community of UIN Sulthan Thaha Saifuddin Jambi conducted by making a fundraising list through WA Group (Figure 2.) Or through the poster (Figure 3.). When the fundraising is done so that this activity can be carried out routinely, it does not depend on the funds from the university budget.

The special month of Ramadan 1442H/2021M food sharing activities are carried out every day and distributed to everyone who passes in front of UIN STS Jambi Telanaipura Campus. Food distribution was carried out by DWP UIN STS Jambi members and volunteers of the Center for Demographic Studies, Ethnography, and Social Transformation UIN Sulthan Thaha Saifuddin Jambi. 


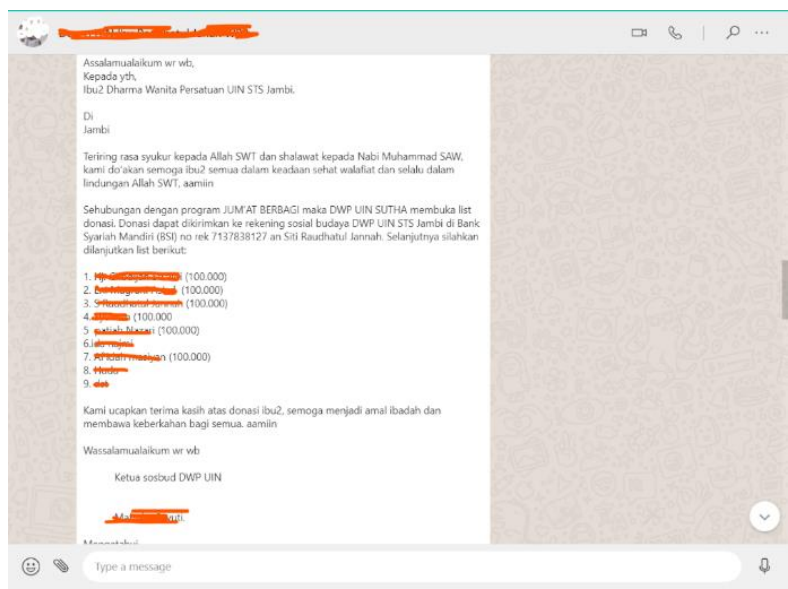

Fig. 2. fundraising list at WA Group

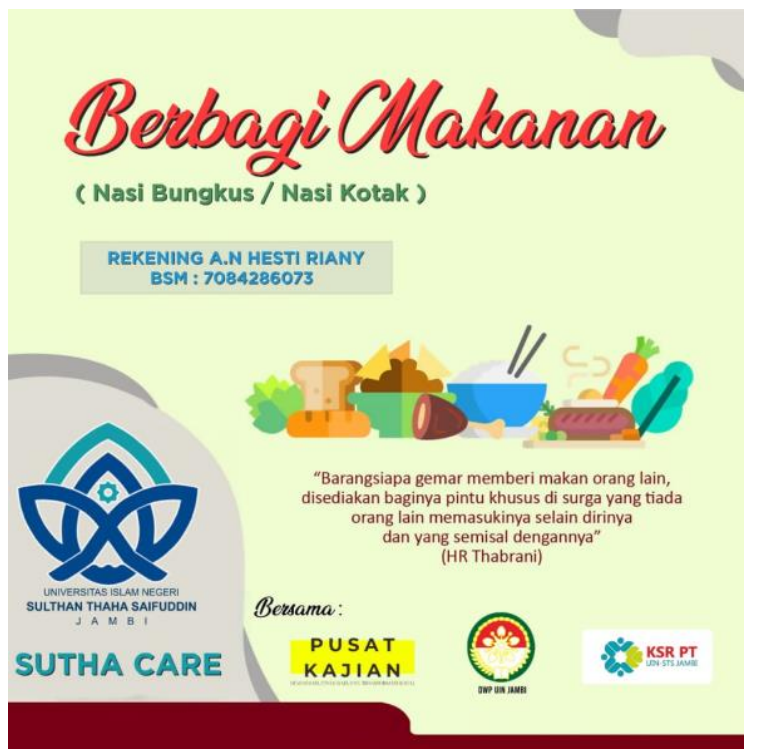

Fig. 3. Fundraising Posters Using Poster/flyer

\section{Results and discussion}

Results from the survey of identification of students and staff in need showed that $31.75 \%$ of student living costs amounted to Rp500,000 - Rp1,000,000, even there are still students with living costs of $<\mathrm{Rp} 300,000$ as much as $26 \%$ (Figure 2). The survey also provided information that $51 \%$ of college students ate two times, while $49 \%$ ate three times.

Crosstab results from the cost of living and the frequency of daily meals displayed in Figure 3 showed that students with the cost of living <Rp500,000 only ate two meals, whereas in general, Indonesians eat as much a day as three times. However, there are also students with a living cost 
of Rp500,000-Rp1,000,000 eating two times a day. The figure shows that the culture of eating two times a day has begun to be done a lot.

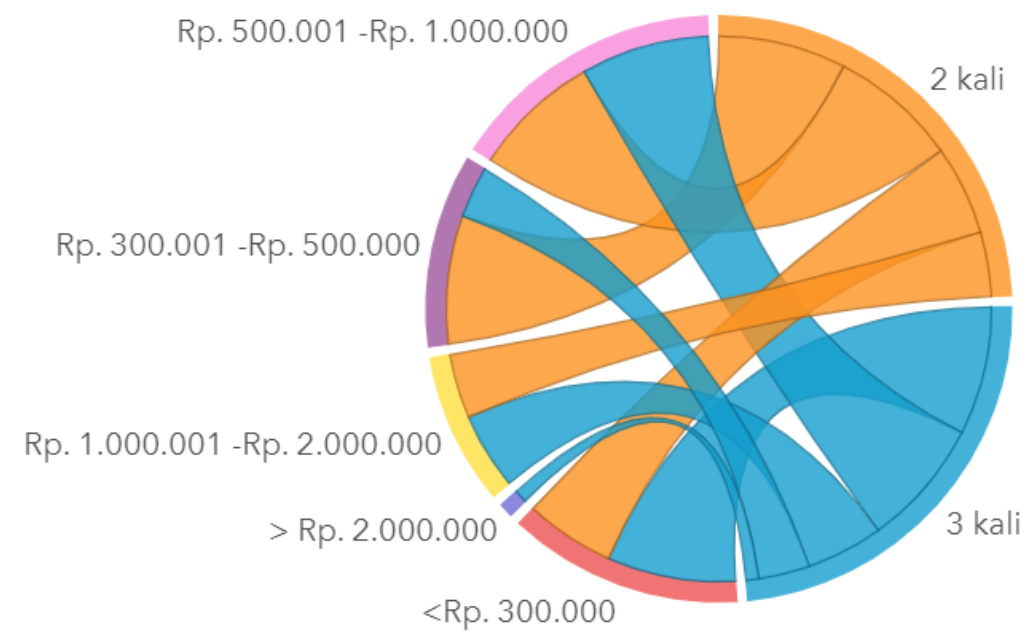

Fig. 4. Chord Diagram between Live Cost and daily meal frequency

The diagram in Figure 4 still needs to clarify the distribution of student meals that are only two times at each income level. Therefore, it is necessary to find out the reason why students eat only two times. Based on Figure 5 below, college students miss one of the food schedules is the $1 \%$ diet. Unable to buy food as much as $3 \%$ and $48 \%$ passed one of the food schedules. The result shows that there are still students who need, which is about $3 \%$ of students who are dominated by students who take as mosque keeper (takmir). 


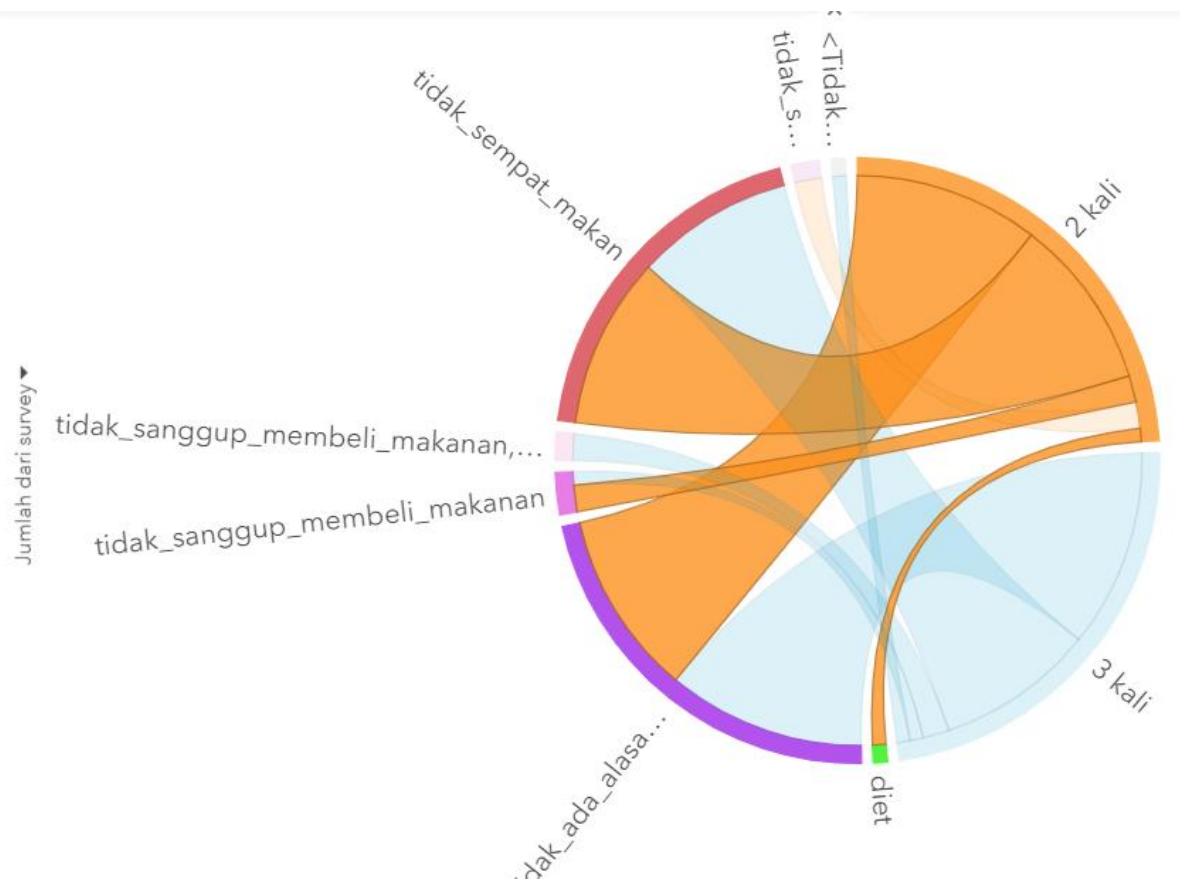

Fig. 5. Diagram Chord between Reasons to miss one of the meal schedules and daily meal frequency

After knowing the result, the Center Of Demographic Studies, Ethnographic, and Social Transformation, in collaboration with DWP UIN STS Jambi, took the initiative to implement Friday Charity Program, which benefits students and staff who need it.

In addition to helping students with Friday charity activities, also distribute food assistance to contract staff. The number of staff who deserve to be helped based on data collected as many as 90 people consisting of 25 security guards and 65 Cleaning Services. This election is based on a heavy workload with and assumptions of family dependents. If given food assistance, they can save expenses from the salary earned per month [22].

Sharing activities in Indonesia are still partially carried out. [13]-[19], [23], [24] both university involvement and CSR. Friday Charity Program implemented by UIN Sulthan Thaha Saifuddin Jambi is carried out sustainably by arranging the distance of activities once every two weeks.

All figure below is documentation of Friday Charity activities: distributing free food to cleaning services at Simpang Sungai Duren Campus and Telanaipura Campus (Figure 6). Distribute free food to security guards at Simpang Sungai Duren Campus and Telanaipura Campus (Figure 7). Free food to students (Figure 8). Distribute free food to students and campus staff who perform Friday prayers at the campus mosque (Figure 9). DWP and KSR UIN STS Jambi distribute free food during Ramadan (Figure 10) and food distribution to the community in Ramadan (Figure 11). 


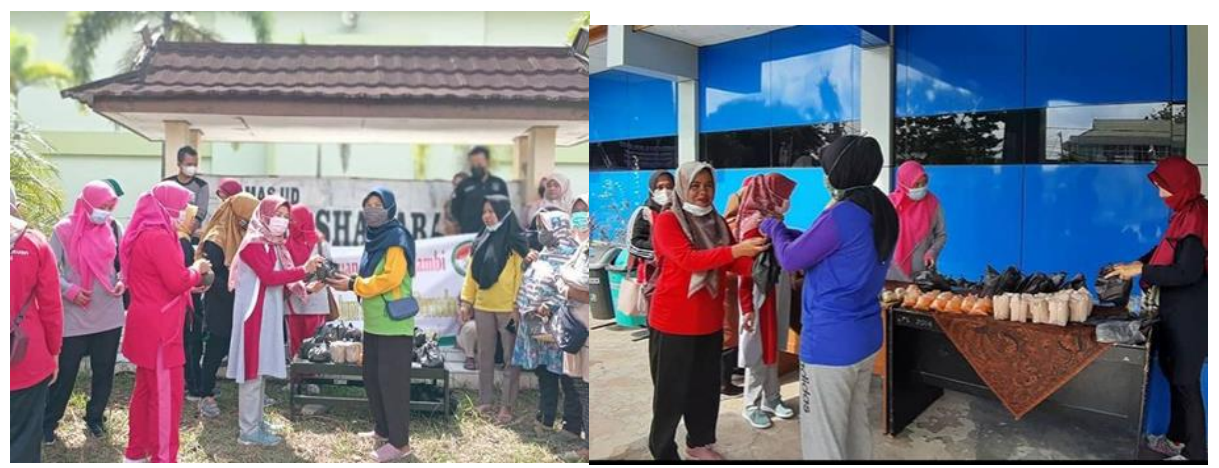

Fig. 6. Free food distribution for cleaning services at Simpang Sungai Duren Campus and Telanaipura Campus

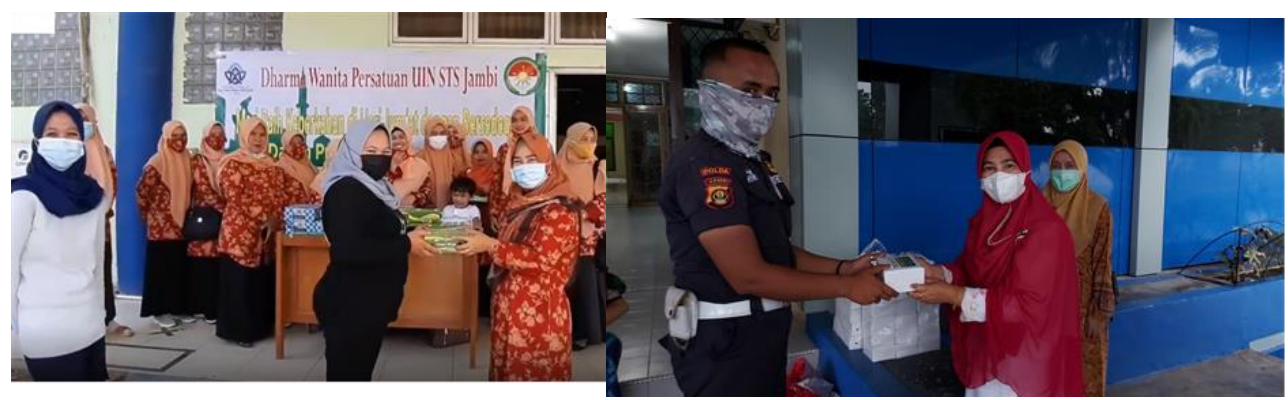

Fig. 7. Free food distribution for security guards at Simpang Sungai Duren Campus and Telanaipura Campus

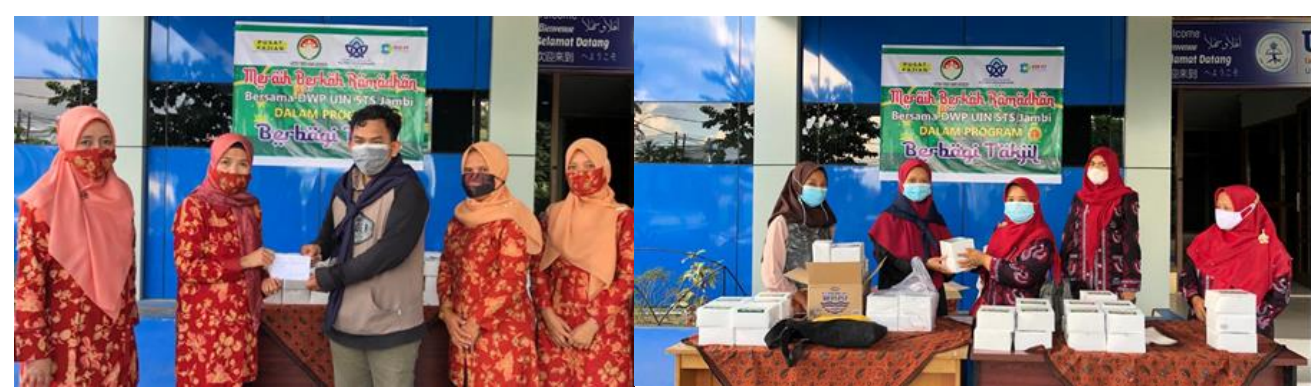

Fig. 8. Free food distribution for students UIN STS Jambi 


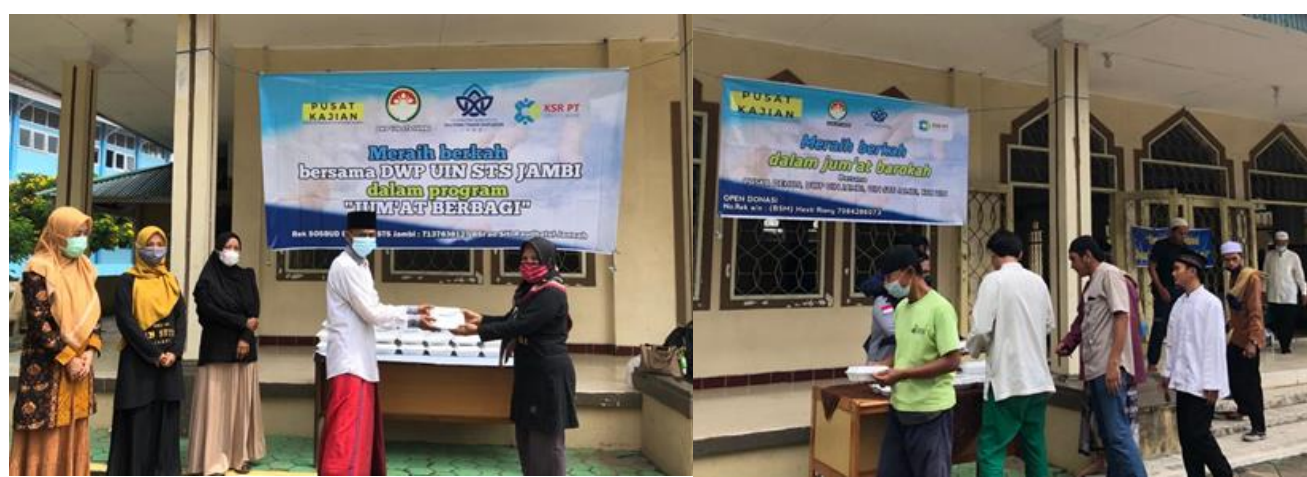

Fig. 9. Free food distribution for UIN STS Jambi Students and Staff after Friday prayers (sustainably)

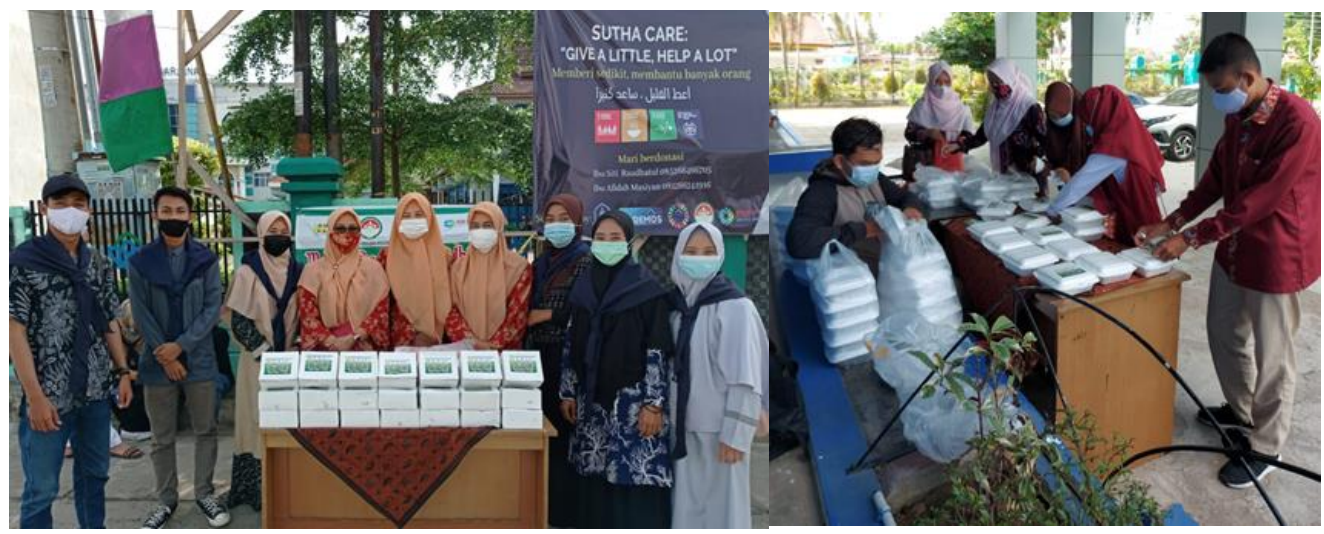

Fig. 10. Involvement of KSR and DWP UIN STS Jambi in distributing free food in Ramadan

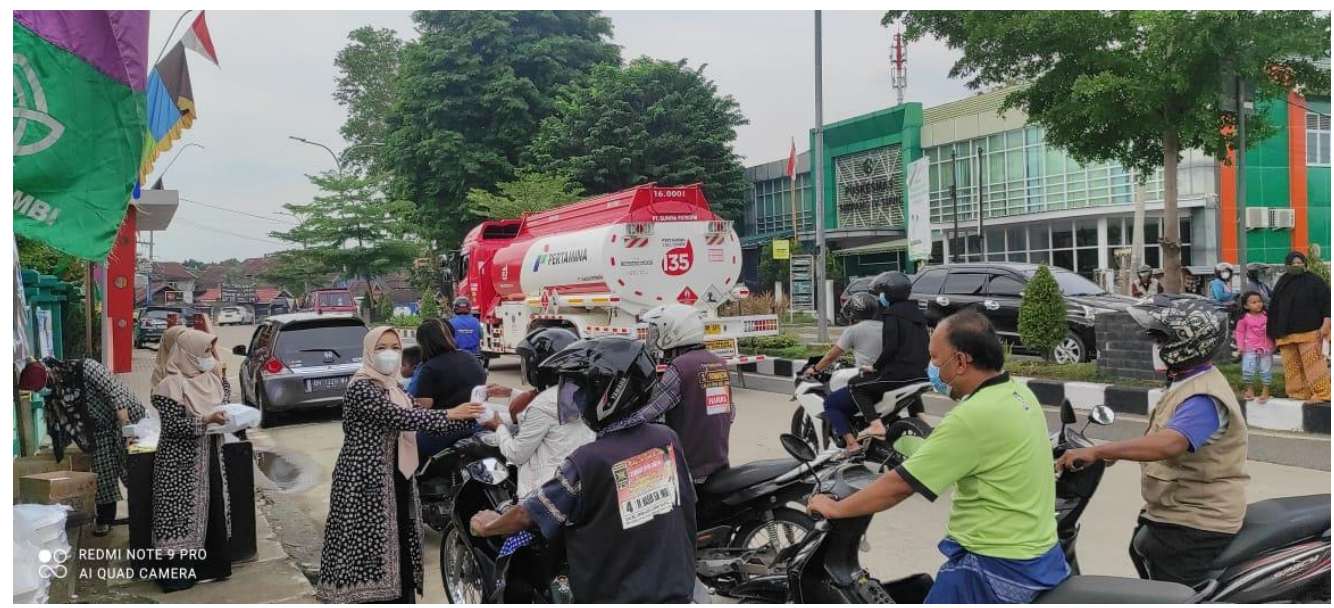

Fig. 11. Distribution of free food to the people who passed in front of UIN STS Jambi Telanaipura Campus 


\section{Conclusion}

Friday Charity Program is essential to have an impact on increasing concern for the fellow academic community of UIN STS Jambi and the community around UIN STS Jambi. The Friday Charity activities are expected to increase the involvement of the academic community of UIN STS Jambi in achieving the 2nd Sustainable Development Goals (SDGs) goal, namely No Hungry. This agenda also have the purpose of preventing food insecurity.

Acknowledgments. Thanks to Dharma Wanita Persatuan (DWP) and Korsp Sukarelawan (KSR) UIN STS Jambi for supporting the program. Also, the respondent has to fill the form to identify the student who needs help to meet SDGs No. 2.

\section{References}

[1] Ihsanuddin, "Ini Pengumuman Lengkap Jokowi soal 2 WNI Positif Corona," kompas.com, 2020. https://nasional.kompas.com/read/2020/03/02/12002701/ini-pengumuman-lengkap-jokowi-soal-2wni-positif-corona?page=all (accessed Aug. 16, 2021).

[2] Gresi Plasmanto, "Pemprov Jambi Konfirmasi Kasus Positif Pertama Corona Covid-19," Liputan6, 2020. https://www.liputan6.com/regional/read/4209526/pemprov-jambi-konfirmasikasus-positif-pertama-corona-covid-19 (accessed Aug. 04, 2021).

[3] BPS, "Pertumbuhan Ekonomi Indonesia Triwulan IV-2020," 2021. [Online]. Available: https://www.bps.go.id/pressrelease/2021/02/05/1811/ekonomi-indonesia-2020-turun-sebesar-2-07persen--c-to-c-.html.

[4] M. Nicola et al., "The socio-economic implications of the coronavirus pandemic (COVID-19): A review," Int. J. Surg., vol. 78, pp. 185-193, 2020, doi: 10.1016/j.ijsu.2020.04.018.

[5] M. Power, B. Doherty, K. Pybus, and K. Pickett, "How Covid-19 has exposed inequalities in the UK food system: The case of UK food and poverty," Emerald Open Res., vol. 2, p. 11, Apr. 2020, doi: 10.35241/emeraldopenres.13539.1.

[6] D. Karouw, "Jambi Terapkan PPKM Level 4 Mulai Hari Ini, 24 Titik Pintu Masuk Disekat," iNews.id, 2021. https://regional.inews.id/berita/jambi-terapkan-ppkm-level-4-mulai-hari-ini-24-titikpintu-masuk-disekat (accessed Aug. 23, 2021).

[7] I. Raga and W. Prasetiyo, "Wagub DKI: Jakarta Sudah Zona Hijau dan Memenuhi Herd Immunity," kumparan.com, 2021. https://kumparan.com/kumparannews/wagub-dki-jakarta-sudahzona-hijau-dan-memenuhi-herd-immunity-

$1 \mathrm{wNhrn} 1 \mathrm{EYyw}$ ?utm_campaign=kurio\&utm_medium=Aggregator\&utm_source=kurio $\quad$ (accessed Aug. 23, 2021).

[8] Suyadi, Strategi Pembelajaran Pendidikan Karakter, 1st ed. Bandung: Remaja Rosdakarya, 2013.

[9] Lembaran Negera Republik Indonesia, Undang-undang (UU) No 12 tahun 2012 tentang Pendidikan Tinggi. Indonesia, 2012, pp. 1-97.

[10] L. P. Symaco and M. Y. Tee, "Social responsibility and engagement in higher education: Case of the ASEAN," Int. J. Educ. Dev., vol. 66, pp. 184-192, Apr. 2019, doi: 10.1016/J.IJEDUDEV.2018.10.001.

[11] F. Men and V. Tarasuk, "Food Insecurity amid the COVID-19 Pandemic: Food Charity, Government Assistance, and Employment," Can. Public Policy, vol. 47, no. 2, pp. 202-230, Jun. 2021, doi: 10.3138/cpp.2021-001.

[12] A. Rangone and L. Busolli, "Managing charity 4.0 with Blockchain: a case study at the time of Covid-19," Int. Rev. Public Nonprofit Mark., 2021, doi: 10.1007/s12208-021-00281-8.

[13] D. Dan, B. Paket, and S. Peduli, "PENGABDIAN MASYARAKAT GERAKAN BAKTI SOSIAL PENYEMPROTAN DISINFEKTAN DAN BERBAGI PAKET SANTUNAN PEDULI 
COVID-19 DI PONDOK PASENTRAN BUKIT TENGKORAK NDAO KABUPATEN ENDE FLORES," vol. 4, pp. 638-644, 2021.

[14] S. Salasiah, D. Diana, M. A. Fatah, and M. A. Adriansyah, "Membangun Kepedulian Pada Sesama di Masa COVID-19," Plakat (Pelayanan Kpd. Masyarakat), vol. 2, no. 2, p. 160, 2020, doi: 10.30872/plakat.v2i2.4973.

[15] T. Awaludin, A. W. Lestari, E. Cahyadi, E. Savitri, and S. A. Yughi, "PENINGKATAN MOTIVASI DIRI DAN BERBAGI BERSAMA WARGA TENAGA KERJA INFORMAL TERDAMPAK COVID 19 DI KELURAHAN KUKUSAN KECAMATAN BEJI KOTA DEPOK," Dedik. PKM, vol. 1, no. 3, p. 55, Sep. 2020, doi: 10.32493/dedikasipkm.v1i3.6687.

[16] S. E. Martina, Amila, and Evarina Sembiring, "PEDULI COVID-19, BERBAGI MASKER PADA PEDAGANG PASAR TRADISIONAL," AMALIAH J. Pengabdi. Kpd. Masy., vol. 4, no. 2, pp. 176-185, Nov. 2020, doi: 10.32696/ajpkm.v4i2.521.

[17] J. Z. Hafizd, "Peran Bank Syariah Mandiri (Bsm) Bagi Perekonomian Indonesia Di Masa Pandemi Covid-19," Al-Mustashfa J. Penelit. Huk. Ekon. Syariah, vol. 5, no. 2, p. 138, 2020, doi: 10.24235/jm.v5i2.7402.

[18] R. Apriani, E. Selvi, and P. S. Putra, "Sosialisasi Pemanfaatan Corporate Social Responsibility (Csr) Dalam Menormalisasi Kembali Iklim Usaha Bagi Umkm Di Karawang,” Al-Khidmat, vol. 4, no. 1, pp. 16-21, 2021, doi: 10.15575/jak.v4i1.10370.

[19] C. Muna, M. Y. Saifulloh, and F. Sodik, "Pemberdayaan Masyarakat di Masa Pandemi COVID19 oleh PT. Pertamina (Persero) RU II Sungai Pakning," Empower J. Pengemb. Masy. Islam, vol. 5, no. 2, p. 57, 2020, doi: 10.24235/empower.v5i2.7269.

[20] W. Wahyuningsih, "Millenium Develompent Goals (Mdgs) Dan Sustainable Development Goals (Sdgs) Dalam Kesejahteraan Sosial,” Bisma, vol. 11, no. 3, p. 390, 2018, doi: 10.19184/bisma.v11i3.6479.

[21] ESRI, "ArcGIS Survey123 Smarter forms, smarter data collection," ESRI, 2019. https://www.esri.com/en-us/arcgis/products/arcgis-survey123/overview (accessed Oct. 18, 2021).

[22] G. Rasul et al., "Socio-Economic Implications of COVID-19 Pandemic in South Asia: Emerging Risks and Growing Challenges," Front. Sociol., vol. 6, no. 629693, pp. 1-14, Feb. 2021, doi: $10.3389 /$ fsoc. 2021.629693 .

[23] A. Iskandar, B. T. Possumah, and K. Aqbar, "Peran Ekonomi dan Keuangan Sosial Islam saat Pandemi Covid-19," SALAM J. Sos. dan Budaya Syar-i, vol. 7, no. 7, pp. 625-638, 2020, doi: 10.15408/sjsbs.v7i7.15544.

[24] C.-K. Babakan and K. Tangerang, "Berbagi Bersama Untuk 30 Warga Yang Terdampak," vol. 1, no. 2, pp. 1-5, 2020. 